\title{
El cincuentenario de la histeria (1878-1928) ${ }^{1}$
}

Nosotros, surrealistas, queremos celebrar aquí el cincuentenario de la histeria, el mayor descubrimiento poético de finales del siglo XIX, y esto en el momento mismo en que el desmembramiento del concepto de histeria parece un hecho consumado. Nosotros, que nada amamos tanto como a esas jóvenes histéricas, cuyo tipo perfecto nos lo facilitó la observación relativa a la deliciosa X. L. (Augustine) ingresada en la Salpêtrière en el Servicio del doctor Charcot el 21 de octubre de 1875 a la edad de quince años y medio, estamos muy afectados por la laboriosa refutación de los trastornos orgánicos, cuyo proceso no será el de la histeria más que a ojos de los simples médicos. ¡Qué lástima! Babinski, el hombre más inteligente que haya acometido este empeño, osaba publicar en 1913: «Cuando una emoción es sincera, profunda, e impresiona al alma humana, ya no hay lugar para la histeria». Esto no deja de repetírsenos. Freud, quien debe tanto a Charcot, recuerda la época en que, según el testimonio de los supervivientes, los internos de la Salpêtrière confundían sus deberes profesionales y sus afanes amorosos cuando, al caer la noche, las enfermas se veían con ellos fuera o les recibían en su cama. Luego enumeraban pacientemente, en pro de la causa médica que no se defiende, las posturas pasionales llamadas patológicas que les eran, y nos son todavía humanamente, tan preciosas. Cincuenta años después, ¿ha muerto la escuela de Nancy? ¿Se le ha olvidado todo esto al doctor Luys, si es que vive todavía? ¿Pero dónde están las observaciones de Neri sobre el terremoto de Mesina? ¿Dónde están los zuavos torpedeados por el Raymond Roussel de la ciencia, Clovis Vincent?

A las diversas definiciones de la histeria que se han dado hasta hoy día, la histeria divina en la Antigüedad, la infernal en la Edad Media, de los poseídos de Loudun a los flagelantes de Nôtre Dame des Pleurs (¡viva madame Chantelouve!), definiciones míticas, eróticas o simplemente líricas, definiciones sociales, definiciones científicas, es demasiado fácil oponer la de «enfermedad compleja y proteiforme llamada histeria que escapa a toda definición» (Bernheim). Seguro que los espectadores de la hermosa película La brujería a través de las épocas recordarán haber encontrado en la pantalla o en la sala enseñanzas más vivas que las de los libros de Hipócrates o de Platón donde el útero brinca como una cabritilla, de Galeno que inmoviliza a la cabra, de Fernel que la vuelve a hacer andar en el siglo XVI y la siente bajo su mano remontarse hasta el estómago; han visto crecer, crecer los cuernos de la bestia hasta convertirse en los del diablo. A su vez el diablo hace mutis por el foro. Las hipótesis positivistas se reparten su herencia. La crisis de histeria toma forma a expensas de la histeria misma, con su aura soberbia, sus

1 Louis ARAgON, André Breton, «Le cinquantenaire de l'hystérie», La révolution surréaliste, 11, 15-31928, pp. 20-22; trad. Ángel Cagigas. 
cuatro etapas de las que la tercera nos paraliza como los cuadros vivos más expresivos y más puros, su resolución simple a la vida normal. En 1906 la histeria clásica pierde sus rasgos: «La histeria es un estado patológico que se manifiesta a través de trastornos que se pueden reproducir mediante sugestión, en algunos sujetos, con una exactitud perfecta y que son susceptibles de desaparecer bajo la influencia de la simple persuasión (contrasugestión)» (Babinski).

No vemos en esta definición más que un momento del devenir de la histeria. El movimiento dialéctico que la ha hecho nacer sigue su curso. Diez años más tarde, bajo el disfraz deplorable del pitiatismo, la histeria se dispone a recuperar sus derechos. El médico se queda atónito. Quiere negar lo que no le incumbe.

Así pues, nosotros proponemos, en 1928, una definición nueva de la histeria: «La histeria es un estado mental, más o menos irreducible, que se caracteriza por la subversión de las relaciones que se establecen entre el sujeto y el mundo moral del cual cree depender, al margen de todo sistema delirante. Este estado mental se funda en la necesidad de una seducción recíproca que explica los milagros apresuradamente aceptados de la sugestión (o contrasugestión) médica. La histeria no es un fenómeno patológico y a todos los efectos puede considerarse como un medio supremo de expresión». 